\title{
BENTUK EVALUASI BELAJAR SDIT GLOBAL CENDIKIA
}

\author{
Miftahul Jannah Alfarizi \& Shabrina \\ Universitas Muhammadiyah Tangerang \\ miftahul.jannah@umt.ac.id
}

\begin{abstract}
This research is motivated by the problem that there is no defivinitive learning evaluation standard for children who have advantages and disadvantages even though they get aducational services in incluve classes. Therefor,this study aims to find solutions to solving problems of learning evaluation planning systems, forms of evaluation forms of reporting of evaluation results. Which is included in the inclusive class of this study is focused on planning the evaluation of learning, the form of evaluation carried out, and the form of evaluation reports that have been carried out in inclusive classes contained in the GLOBAL CENDEKLA SCHOOL AR this research was conducted by interview, observation, documentation methods.
\end{abstract}

Keywords : Learning, Learning Evaluation

\begin{abstract}
Abstrak : Penelitian ini dilatar belakangi permasalahan belum ada standar evaluasi pembelajaran yang pasti untuk anak yang memiliki kelebihan dan kekurangan, walaupun mereka mendapat pelayanan pendidikan di kelas inklusif Karena itu penelitian ini bertujuan untuk mencari solusi pemecahan Masalah bagaimana sistem perencanaan evaluasi pembelajaran, bentuk evaluasi, bentuk pelaporan hasil evaluasi yang terdapat di kelas inklusif Penelitian ini difokuskan pada perencanaan evaluasi pembelajaran, bentuk evaluasi yang dilakukan, dan bentuk laporan evaluasi yang telah dilakukan di kelas inklusif yang terdapat di SDIT GLOBAL CENDIKIA Penelitian ini dilakukan dengan metode interview,observasi dan dokumentasi.
\end{abstract}

Kata Kunci: Pembelajaran, Evaluasi Belajar

\section{PENDAHULUAN}

Dalam aplikasi pembelajaran yang dilaksakan di sekolah tentu pada akhirnya ingin di ketahui hasil dari pembelajaran tersebut. Hal itu dimaksudkan untuk mengetahui perkembangan prestasi belajar,instrument yang di pergunakan pada umumnya adalah evaluasi. Sedang bentuk evaluasi ada beberapa macam, seperti,ujian tulis,lisan,partisipasi siswa dikelas dan sebagainya.hasil evaluasi tersebut akhirnya terakumulasi dalam nilai rapot. 
Evaaluasi merupakan salah satu kegiatan yang sangat penting dalam proses pembelajaran.untuk mengetahui kemajuan atau prestasi belajar siswa,perlu dilakukan kegiatan evaluasi pembelajaran.evaluasi pembelajaran adalah evaluasi yang diterapkan dalam kegiatan pembelajaran.

Evaluasi juga dapat diartikan sebagai suatu proses mendeskripsikan, mengumpulkan dan menyajikan suatu informasi yang bermanfaat untuk pertimbangan dalam pengambilan keputusan. fungsi uutama evaluasi adalah menelaah suatu objek atau keadaan untuk mendapatkan informasi yang tepat sebagai dasar untuk pengambilan keputusan.

Evaluasi pebelajaran merupakan evaluasi yang dilaksanakan Dalam bidang pembelajaran. Dalam kata lain, evaluasi pembelajaran merupakan suatu proses kegiatan menelaah atau menilai aspek-aspek dalam kegitan pembelajaran, baik dari sisi konteks, input, proses, maupun hasil-hasil pembelajaran.hal ini sesuai dengan pendapat gronlund dan lin dalam budi wiyono (2004:3) yang mengatakan bahwa evaluasi pembelajaran adalah suattu proses mengumpulkan, menganalisis, dan menginterprestasi informasi secara sistematis unntuk menetapkan sejauh mana ketercapaian tujuan pembelajaran. Sasaran utama evaluasi pembelajaran adalah informasi yang dapat di gunakan sebagai dasar untuk pengambilan keputusan dalam proses kegiatan pembelajaran.

\section{METODE PENELITIAN}

\section{Jenis Penelitian}

Penelitian ini menggunakan jenis penelitian kualitatif studi kasus. Dalam penelitian ini, mengumpulkan data deskriptif yang diperoleh melalui observasi, wawancara, dan dokumentasi.

\section{Waktu dan Tempat Penelitian}

Penelitian ini dilaksanakan di SDIT GLOBAL CENDIKIA yang beralamat di KP. Doyong RT 05/13 Kel. Gembor Kec. Periuk Kota Tangerang. pada tahun ajaran 2019/2020. Penelitian ini dilaksanakan Lokasi tersebut dipilih berdasarkan pertimbangan penelitian karena 


\section{Target/Subjek Penelitian}

Subjek dalam penelitian ini adalah siswa kelas V dan VI di SDIT GLOBAL CENDIKIA.

\section{Prosedur}

Penelitian ini menggunakan tipe penelitian kualitatif. Data diperoleh melalui dari proses obervasi, wawancara, dokumentasi, dan catatan lapangan. Dari pengumpulan informasi melalui observasi, wawancara, dokumentasi dan catatan lapangan, kemudian penyimpulan pengatasan dan penyimpulan hasil.

\section{Data, Intrumen, dan Teknik Pengumpulan Data}

Teknik pengumpulan data dalam penelitian menggunakan teknik observasi, wawancara, dokumentasi, dan catatan lapangan. Teknik pengumpulan data dalam penelitian ini dengan melakukan wawancara terhadap murid kelas VdanVI. Peneliti juga melakukan dokumentasi dan membuat catatan lapangan sebagai upaya untuk kelengkapan data. Selain itu peneliti juga menggunakan kuesioner yang dilakukan dengan cara memberi seperangkat pertanyaan atau pernyataan tertulis kepada murid kelas V dan VI di SDIT GLOBAL CENDIKIA.

\section{Teknik Analisis Data}

Teknik data dilakukan sesuai dengan prosedur ilmiah penelitian kualitatif. Pada penelitian ini menggunakan metode analisis dari Milles dan Huberman. Dalam teknik analisis ini terdapat tiga tahap yaitu reduksi data, penyajian data, dan verifikasi data. Reduksi data bertujuan untuk menyederhanakan data yang abstrak menjadi sebuah rangkuman yang jelas dan terperinci. Data tersebut dihasilkan dari proses obervasi, wawancara, dakumentasi, dan catatan lapangan. Proses selanjutnya adalah penyajian data. Setelah direduksi kemudian data disajikan kedalam bentuk yang lebih sederhana dalam bentuk paparan naratif dan hasil penelitian tentang bentuk evaluasi belajar. Kemudian langkah terakhir adalah verifikasi data. Data yang telah diproses kemudian ditarik kesimpulan. Penyimpulan merupakan proses pengambilan intisari data sajian yang telah terorganisir tersebut dalam bentuk pertanyaan kalimat yang singkat dan padat tetapi mengandung pengertian yang luas. Hasil analisis disusun untuk mengetahui kemampuan siswa. 


\section{HASIL PENELITIAN DAN PEMBAHASAN}

Adapun terkait dengan system evaluasi pembelajaran pada jenjang SD yang dilakukan oleh seorang guru terhadap siswanya untuk mengetahui apakah proses pembelajaran sudah mencapai tujuan pendidikan atau sebaliknya, baik denagn Tanya jawab,kuisioner, latihan-latihan, dan pada saat ujian tengah semester ataupun ujian akhir semester. Banyak yang kita lihat di sekolah-sekolah para guru selalu mengadakan evaluasi pembelajaran kepada peserta didik dengan tujuan untuk mengetahui sejauh mana tingkat kemampuan peserta didiknya dalam memahami materi yang telah di berikan oleh guru dalam kegiatan proses belajar mengajar. Adapun evaluasi yaitu bagian dari proses belajar mengajar yang secara keseluruhan tidak dapat dipisahkan dari kegiatan mengajar yang di lakukan oleh seorang guru. Ada beberapa tingkah laku yang sering muncul serta menjadi perhatian seorang guru. Dan tingkah laku yang di kelompokkan menjadi tiga bagian, antara lain: pengetahuan intelektual, keterampilan, sikap.

Adapun evaluasi yang harus dilakukan secara sistematis dan continue agar dapat memperoleh gambaran tenteng tingkat kemampuan dari siswa atau peserta didik tapi masih ada juga guru dalam mengevaluasi siswanya pada saat-saat tertentu. Seperti pada akhir atau pertengahan suatu program pengajaran. Jadi, akibatnya guru memperoleh informasi yang minim tentang para siswa-siswa nya sehingga menyebabkan banyaknya perlakuan prediksi guru menjadi bias dalam menentukan posisi dari siswa tersebut dalam kegiatan dikelasnya.

Selain itu adapun seorang guru perlu memahai metode dari evaluuasi. Yang dimaksud dari metode evaluasi disini adalah cara atau strategi evaluasi yang digunakan oleh seorang guru agar memperoleh informasi yang di perlukan. Tugas guru dalam melakukan evaluasi yaitu membantu siiswa daam mencapai tujuan umum dari pendidikan yang telah di tetapkan. Agar tercapai tujuan pendidikan yang di maksud, seorang guru perlu bertindak secara aktif dalam membantu setiap langkah dalam proses pembelajaran. 
Selain itu adapun fungsi maupun tujuan dari di adakan nya evaluasi pembelajaran terhadap siswa atau peserta didik, antara lain:

1. Evaluasi dsni sebagai alat untuk mengetahui apakah siswa atau peserta didik tersebut telah menguasai pengetahuan, keteramplan, atau materi pembelajaran yang telah di berikan oleh seorang guru.

2. Untuk mengetahui kelemahan atau kekurangan siswa dalam melakukakn kegiatan belajar.

3. Untuk mengetahui tingkat ketercapaian peserta didik dalam kegiatan pembelajan.

4. Sebagai sarana umapan balik bagi seorang guru yang bersumber dari siswa tersebut.

5. Sebagai alat untuk mengetahui sampai mana perkembangan siswa tersebut.

6. Sebagai laporan hasil belajar peserta didik yang di berikan kepada orang tua sebagai bukti sampai mana tingkat kemampuan siswa tersebut, misalnya berupa rapot.

Secara garis besar,metode evaluasi dalam pendidikan dapat di bedakan menjadi dua bentuk, yaitu tes dan non tes. Evaluasi dalam bentuk tes biasanya di lakuakan dengan tes tertulis yang dimana tes tertulis disini ada dua macam yaitu tes objektif dan tes esay. Tes tertulis tersebut di gunakan untuk mengumpulkan data kuantitatif pengetahuan secara komperhensif tes ini biasanya di berikan denagn suatu ithem pertanyaan menghafal yang diantaranya sebagai jawaban bebas, melengkapi, fan mengidentifikasi.

Dan evaluasi dalam bentuk non tes yang di guanakan untuk mengevaluasi penampilan dan aspek-aspek belajar efektif dari siswa atau peserta didik. Alat tersebut dapat juga di gunakan untuk mengevaluasi tingkah laku seperti sikap, interaksi sosial, dan sebagainya.

Oleh karna itu, kita sebagai seorang guru atau calon pendidik perlu melalukan evaluasi terhadap belajar siswa untuk mengetahui sejauh mana tingkat kemampuan 
siswa tersebut dalam mengikuti proses kegiatan belajar di kelas. Tapi bukan hanya siswa saja yang harus di evaluasi melainkan guru juga harus di evaluasi untuk mengetahui apakah udah maksimal dalam menyampaikan pembelajaran kepada peserta didik atau sebaliknya

\section{KESIMPULAN}

Evaluasi merupakan pengukuran program pendidikan, perencanaan suatu program substansi pendidikan, termasuk kurikulum dan pelaksaaanya, pengadaan dan peningkatan kemampuan guru, pengelolaan pendidikan, dan reformasi pedidikan secara keseluruhan. Sekolah harus menentukan batas-batas kesanggupan ketercapaian penyesuaian pada tuntutan-tuntutan kehidupan waktu sekarang dan yang akan datang, yang dapat dicapai siswa sebagai hasil pengalaman-pengalaman belajarnya. Teknik-teknik dalam evaluasi hasil belajar penting untuk melihat hasil-hasil yang diperoleh dari penyelenggaraannya supaya bernilai praktis dalam usaha pembangunan pendidikan modern di atas puing-puing yang lama. Dan setiap jenis atau bentuk butir soal mempunyai cara penilaian atau Skoring-nya masing-masing.

\section{DAFTAR PUSTAKA}

Arikunto, Suharsimi.2005. Dasar-dasar Evaluasi Pendidikan.Jakarta:Bumi Aksara. Asep Jihad dan Abdul Haris. 2013. Evaluasi Pembelajaran. Bantul: Multi Pressindo.

Nurkancana, Wayan dan Sunartana. 1992. Evaluasi Hasil Belajar. Surabaya: Usaha Nasional.

Rahayu, try (2015) guru dalam mengevaluasi belajar siswa

Wiyono, bambang budi (2004). Evaluasi pembelajaran,malang 